\title{
THE SOCIAL AND FAMILY INTERACTION OF ADOLESCENT WITH PORNEOGRAPHY ADDICTION IN THE BORNEO MADANI FOUNDATION OF SAMARINDA, INDONESIA
}

\author{
Rosdiana ${ }^{1}$, Godefridus Bali Geroda ${ }^{2}$ \\ Email : anahanur@gmail.com \\ 1,2Universitas Widya Gama Mahakam Samarinda Indonesia
}

\section{ABSTRACT}

During their development, adolescents experience emotional, cognitive, and psychological changes. One of the changes that cannot be avoided is motivation and high curiosity about various things that happen to them, including problems related to sexuality. The availability of sophisticated technology makes it easy to access pornographic content so that many teenagers enjoy and become addicted. Lifestyle, lack of supervision, lack of good communication, too high demands, violence against children, not knowing the potential of children and discrimination from parents and the environment can trigger adolescents to be exposed to pornography. This research is used qualitative research methodology with a case study approach through in-depth interviews, observation, and documentation to 15 informants. The objective of this research is to determine the impact of the social and family environment due to pornography addiction. The results showed that, the impact on the social environment, increasing adolescent sexual exploration so that free sex and risky sexual behavior can occur, changing attitudes and perceptions about sexuality that women and children are sex objects only, easily lie with anyone because they do not care about price self and self-concept, it's easy to hurt others to channel their passions. The impact on the family environment, the difficulty in concentrating in the learning process and carrying out daily activities that require attention, so that parents are often reprimanded and even scolded by parents at home because the rooms are dirty and messy and lack of attention or indifference to problems in the family, are not sensitive on the interaction among family members so that there is no warmth, love, and care for each other in family members.

\section{ABSTRAK}

Dalam perkembangannya remaja mengalami perubahan emosional, kognitif dan psikis, salah satu perubahan yang tidak bisa dihindari adalah motivasi dan rasa keingintahuan yang tinggi terhadap berbagai hal yang menimpa dirinya termasuk masalah-masalah yang berhubungan dengan seksualitas. Ketersediaan tekhnologi yang canggih memudahkan dalam mengakses konten pornografi sehingga banyak remaja yang menikmati dan menjadi candu. lifestyle, kurangnya pengawasan, tidak terjalin komunikasi yang baik, tuntutan terlalu tinggi, kekerasan pada anak, tidak mengetahui potensi anak serta diskriminasi dari orang tua dan lingkungan dapat memicu remaja untuk dapat terpapar pornografi. Metodologi penelitian kualitatif dengan strategi pendekatan study kasus, melalui wawancara mendalam, observasi dan dokumentasi kepada 15 informan. Tujuan penelitian mengetahui dampak lingkungan sosial dan lingkungan keluarga akibat kecanduan pornografi. Hasil Penelitian, dampak terhadap lingkungan sosial, Meningkatkan eksplorasi seks remaja sehingga dapat terjadi perilaku seks bebas dan perilaku seksual beresiko, mengubah sikap dan persepsi tentang seksualitas bahwa wanita dan anak-anak merupakan obyek seks saja, mudah berbohong dengan siapa saja karena tidak peduli akan harga diri dan konsep diri, mudah melukai orang lain untuk menyalurkan hawa nafsunya. Dampak terhadap lingkungan keluarga, sulitnya berkonsentrasi dalam proses belajar dan menjalankan aktifitas sehari-hari yang membutuhkan perhatian, sehingga sering ditegur bahkan dimarahi oleh orang tua di rumah karena kamar kotor dan berantakan serta kurang perhatian atau cuek dengan masalah yang ada di dalam keluarga, tidak peka terhadap interaksi sesama anggota keluarga, sehingga tidak terjalin kehangatan, kasih sayang dan saling peduli dalam anggota keluarga.

\section{ARTICLE INFO}

Keywords:

Social Interaction; Teenager; Pornography

Addiction

DOI:

$\underline{10.24252 / \text { kesehatan.v14i2.24857 }}$

Kata kunci :

Interaksi Sosial; Remaja; Kecanduan Pornografi

\section{Introduction}

Addiction to pornography in adolescents is an issue that causes sufferers to have a disorder in the form of addiction to an object whose media is visual (pictures/writing) so that it can have a bad influence on the body and the impact is almost the same or even worse than drugs. This addictive activity can be categorized as the effect of narcotics (1), so pornography addiction is also called narcotics through the eyes (Narcolemma). 
The results of another study published on website The Conversation show that young people who consume pornography tend to develop abusive sexual behavior (2) while the results of research conducted by (3) as a reference for men's sexual style (MSM), having sex with men is a current trend, besides that it can support their lifestyle needs.

Based on a study (4) 75\% of porn lovers in Indonesia are teenagers with an age range of 15-22 years. The percentage of cellular operating system traffic by age group according to the Ministry of Communication and Informatics is $36.3 \%$ aged $18-24,29.8 \%$ aged $25-34,16.5 \%$ of $35-44$ age group, $10 \%$ of $45-54$ age group, $5.1 \%$ age $55-64$. , age $65+$ as much as $2.2 \%$. Teenagers today are so familiar with the internet as if their lives cannot be separated from the internet and social media.

Based on the results of initial observations of juvenile delinquency cases due to pornography in Samarinda recorded at the Indonesian Borneo Madani Foundation in 2016 as many as 21 cases, in 2017 as many as 11 cases, in 2018 an increase of 24 cases and in 2019 until February there were 20 cases with 48 men and 28 women. orang.

\section{Research Methods}

The research design used a qualitative approach with a phenomenological approach, in order to be able to dig deeper into the social interactions of adolescents that cause addiction to pornography. The research was conducted at the Borneo Madani Foundation, Samarinda (YBM). The number of informants is 15 people, consisting of 6 teenagers who are addicted to pornography, 5 parents of teenagers who are addicted to pornography, 1 YBM leader, 1 holder of a coaching program at YBM, 2 school friends who are addicted to pornography. Collecting data to 15 informants through;

\section{In-depth Interviews}

Interviews with 15 informants with the aim of obtaining data directly from the informants about the social interactions of teenagers addicted to pornography in the school environment, family environment and social interactions during the coaching program at YBM. (5)

\section{Observation}

Data obtained through direct observation to informants regarding the behavior and ways of communicating informants in interacting with parents when they come to visit YBM, interaction of informants with fellow pornography addicts in carrying out rehabilitation programs, interactions during the coaching program at YBM. In addition, observations were also made to triangulate data if there were biases or deficiencies at the time of the study or when the data had been verified. (6)

\section{Documentation}

Data strengthening is done through documentation such as report documents from the program holder, attendance documents, visit documents from parents, close family and friends as well as program implementation process documents by informants while at YBM. (7)

Data that has been collected through in-depth interviews with 15 informants, observations and documentation are categorized, reduced, compiled based on research objectives and coded based on data sources, then displayed while being verified, if the data is considered lacking or biased, data collection and triangulation of data through in-depth interviews are carried out. Observation or documentation. If the data obtained is saturated and in accordance with the research objectives, a conclusion is drawn.(8)

\section{Results}

\section{Social Environment}

Based on the results of research conducted by interview, observation and documentation to six main informants regarding the impact of pornography on their social environment. It is known 
The Social and Family Interaction of Adolescent with Porneography Addiction in the Borneo Madani Foundation of Samarinda, Indonesia

that the six informants do not get along with their social environment, either with the environment around their residence or with friends at school. This is because the informants feel like being talked about by the people around them. Informants prefer to be alone than to join their friends. Informants also prefer to be alone, closed and prefer to daydream. This is in accordance with excerpts from interviews and observations that pornography affects adolescent behavior towards the surrounding environment, the following are excerpts from the interview:

Quotation 1:

"Males ehh mereka tukang gosip, apa-apa kah diceritanya, mending sendiri". (W.A1.MKG.25)

Quotation 2:

"Engga terlalu sih biasa aja sama mereka ga dekat-dekat amat ga jauh-jauh amat, kalau ada PR kelompoknya bareng ya bareng, kalau ga ya ga juga". (W.A3.AF.29)

Quotation 2:

"Ga asyik aja bareng mereka, ga nyambung aja, kalau lama-lama dengan mereka tertekan rasanya, makanya jarang gabung mereka, ya...kecuali terpaksa ga ada pilihan". (W.A2.RA.30)

Quotation 4:

"Yaaa...kadang sih ada keinginan seperti dulu, main kumpul bareng teman, sudah pernah coba juga, huuu.. ga bisa lama aku, pikiranku dengan yang diobrolin teman-teman tu beda, jadi ya.. bareng temanpun aku banyak diam, bahkan aku jadi bahan ledekan dikatakan makin sabar, pendiam atau so kalemlah". (W.NS.A4.30)

Based on the data above and strengthening through triangulation methods with the author's observations, informants who are addicted to watching pornographic content, feel unsuitable and have difficulty adapting to the normal habits of their friends, both the theme of conversation/discussion, shared activities and thoughts. So that informants find it difficult to interact and adapt to their social environment and prefer to be alone.

Quotation 5:

"Orang dalam rumah ya ga ada yang tau lah. Ehya dulu pernah sama bapakku, jadi dulu tuh pernah kena kasus karena nonton film kaya gitu bareng dan kegep terus aku di skors dan orang tuaku di panggil ke BK. Mereka cuman bilang "gila nih anak udah gede nih anak udah nonton kaya gituan" cuma mereka jelasin juga pokoknya jangan pernah peraktekin itu dan itu terakhir kali nonton. Itu sih yang mereka bilang, aku sempet malu sih tapikan bapakku tuh orangnya fine ya ga nganggep apa-apa itu serius". (W.A2.RA.19)

Informant was once sanctioned in the form of a one week suspension from school, because he was found to have access to pornographic content in the school environment. The response of the parents was quite surprised and gave a warning, but parental control was weak for the next step, so that the incident was repeated and repeated, both in the school environment by stealth or at home or anywhere it is important to be safe to access the prohibited content.

Quotation 6:

“Dampaknya sih ya pas sekolah aku jadi ga bisa mikir apa-apa eee, belajar tuh pikiranku cuma mikir nanti dirumah nonton film yang mana ya, itu yang kupikirin. Terus kebayang gerakannya, cara melakukannya itu yang semalam gimana ya caranya". (W.A2.RA.16)

Based on the data above, the informants find it difficult to concentrate in following the lessons at their school, and they do not even care about the final grades obtained from each subject that they take. The thing that dominates his mind is pornographic films that he has accessed and 
The Social and Family Interaction of Adolescent with Porneography Addiction in the Borneo Madani Foundation of Samarinda, Indonesia

even looks for ways how to practice it with his partner. As a result of the interview excerpt as follows;

Quotation 7:

"Puas rasanya jika sudah nonton terus diperaktekkan dengan pasangan, itu luar biasa mba bahagianya, sanksi kah ancaman kah itu ga kepikiran lagi dah lewat itu". (W.A2.RA.16)

\section{Family Environment}

Based on the results of in-depth interviews and observations with five main informants and four supporting informants, regarding the impact of narcolemma on the family environment. Informants feel that the relationship with parents and siblings is not as close and intimate as it used to be, there is no longer warmth and affection in the family, as well as distant families feel more distant, as excerpts from the following interview;

Quotation 8:

"Jarang sih karena aku lebih sering sama teman-teman aku terus kalo udah dirumah ya paling di kamar". (W.A1.MKG.22)

Quotation 9:

"Jarang, selain dia jarang dirumah saya juga kerja jadi juga jarang dirumah, kalau dia dirumah pun dikamar aja". (W.B1.HA.6)

Quotation 10:

"Sering-sering juga sih ada acara keluarga, minggu kemaren pengantenan sepupu dari papah, tiap bulan ada acara arisan keluarga mamah, jadi keluarga mamah tu giliran ditempatin rumahnya kumpul arisan gitu, rasanya tiap weekand ada ajah undangan acara keluarga tu, tapi ga pernah ikut, kecuali dipaksa mamah. Dengan keluarga tuh ga dekat, ga akrab tapi masih saling kenallah, beda dengan adikku, he kalau dia tu akrab semua keluarga, sering ngikut orangtua kalau ada acara keluarga". (W.B2.P.12)

Quotation 11:

"Ga ada larangan sih, bapak sama kaka saya juga sering main game online, apa lagi kalo besok libur sampe larut malam tu". (W.RT.P.12)

Based on the data above, it is the role of the small family that has a lot of negative influence on the process of children being addicted to narcotics. As; the lack of family togetherness which causes emotional ties in the family also decreases, there are no rules and controls in the use of gadgets, parents and siblings give negative examples in the use of gadgets, complete facilities and facilities in accessing pornographic content in the family..

Quotation 12:

"Paling ke kamar liatin nanya ngapain, itu kalau aku lama lepa di kamar atau ayah lagi nonton manggil nonton bareng. Perubahannya ga banyak sih, sepertinya bagi orang tuaku nonton pornografi bukan masalah besar. Untung juga ya ga diawasin ketat setelah orangtuaku dapat laporan dari sekolah". (W.A2.RA.21)

After the informant's parents found out that their children often open and watch pornographic videos, there has been no attempt by the parents to help their children get out of this bad habit.

\section{Discussion}

\section{Social Environment}

Physically adolescents who are addicted to pornography are easy to identify, such as; often nervous when meeting face to face and being invited to communicate and avoiding eye contact, not passionate about doing positive things and forgetting good habits that were often done 
before, lazy to study and difficult to concentrate on lessons, difficult to get along with normal friends, like to be alone and closed, difficult to distract from gadgets and easy to anger when reprimanded and limited use of gadgets.

According to (9) who conducted a survey on the number of students who had accessed pornographic content, and the results were $97 \%$ of students had accessed pornographic content through; comics $43 \%$, internet $57 \%$, games $4 \%$, movies/videos $17 \%$, social media $34 \%$, magazines $19 \%$, books $26 \%$ and others $4 \%$. Based on these data, it proves that of the entire population, namely all students in Indonesia, 94\% have accessed pornographic content, with different levels of addiction. In line with the results of research (3) it shows that respondents in the age range of 17-24 years (late teens) are characterized by adolescents starting to appear free to seek identity, desires, interests, feelings of love and the ability to think abstractly develops, fantasize about sexual matters.

Sex education for adolescents is important to do, as the results of research conducted by (10), explain that in Vietnam sex education for adolescents is a necessity. Therefore, it is important for policy makers to pay attention to providing education about sex education to adolescents, both at school and parents at home. The purpose of education is to instill awareness in adolescents to be wise and responsible for the things they do. In line with the results of research conducted (11)

Based on (12) there are six levels of exposure to pornography. 13 key informants experienced addiction to pornography at levels 6 and 7. Symptoms at level 6, there are nine informants who often experience problems in daily life, such as school assignments not being done because they forget or are reprimanded by the teacher while studying in class because they can't focus, caught by the teacher while watching porn videos through gadgets at school, being in the spotlight by normal friends at school, often reprimanded and even scolded by parents at home for dirty and messy rooms and lack of attention and assistance to the environment and other family members. This is because his daily life is filled with only thinking about pornography. Symptoms of level 7, there are four informants who experience feelings of helplessness and feel hopeless if they do not access pornographic content in their spare time, even when they are at school they try secretly to be able to access pornographic content without thinking about the consequences that will be received.

The habit of pornography addicts makes them permissive or sees free sex as a natural thing, not a taboo thing, so they practice free sex outside the supervision of their parents without any burden and guilt. Meanwhile, pornography addict's teenagers who are surrounded by friends who are guided and free from pornography, will tend to feel inferior, closed, and not confident and feel depressed so they prefer to be alone and don't care about their surroundings. This of course destroys the order of norms in society, and destroys harmony, warmth and harmony in the family.

The impact of pornography addiction on the social environment and the people around it, among others; Increasing adolescent sex exploration so that free sex and risky sexual behavior can occur, changing attitudes and perceptions about sexuality that women and children are only sex objects, easy to lie to anyone because they don't care about self-esteem and self-concept, easy to hurt people others to channel their passions.

\section{Family}

The family environment is the initial madrasa for every individual, where from the time of conception to birth in this world, both when they are toddlers, children, teenagers and adults; they receive countless help and education from their parents. . This help and education from parents has a big influence on the formation of character, attitude and behavior in determining the future of the child. A person who is addicted to watching pornographic content (narcolemma) cannot be separated from the influence of his parents or a small family environment, for example; parents give an example of "always using gadgets when together with children or when communicating with children, parents do not make rules or are not firm 
in carrying out the rules that have been made in the family, parents provide complete facilities (gadget complete internet package) routinely) in accessing prohibited content without strict supervision, and the lack of harmony in the family due to the lack of emotional closeness formed in the family.

When parents find out that their children often watch pornographic videos, in addition to calming themselves down, parents also try to talk about the beginning of the habit, or have heart-to-heart discussions with their children. In addition, things that parents need to know are; must first investigate the source of access, know the reason for the child accessing the content, ask the child what is known and understood from the content, give advice to the child how to divert attention and views from pornographic content, and how to manage the mind so that it is free from the influence of pornographic content.

For students who have a high IQ, exposure to pornographic videos can have an impact on difficulty concentrating in the learning process and carrying out daily activities that require attention. Time in thinking is dominated by anxiety, fantasy or imagination; very little time is filled with productive things. Meanwhile, students who have low IQs can have more extreme effects, because they are more helpless to concentrate on useful things that require more focus, such as studying or doing other positive things, so they are often reprimanded and even scolded by their parents at home, because dirty and messy rooms and lack of attention or indifferent to problems that exist in the family, insensitive to interactions with other family members, so that there is no warmth, affection and mutual care between addicts and other families.

This is in line with the results of research conducted by (13) which says that the pornography that teenagers watch is a sexual sensation that is received prematurely, so what happens is that deep impressions are deposited under the conscious brain that can make it difficult for them to concentrate. , unfocused, lazy to study, not passionate about doing proper activities, until they experience shock and disorientation (loss of sight) towards their own identity that they are actually still teenagers.

\section{Conclusion}

\section{Social Environment}

The impact of pornography addiction on the social environment and the people around it, among others; Increasing adolescent sex exploration so that free sex and risky sexual behavior can occur, changing attitudes and perceptions about sexuality that women and children are only sex objects, easy to lie to anyone because they don't care about self-esteem and self-concept, easy to hurt people others to channel their passions.

\section{Family Environment}

The impact of pornography addiction on the family environment, among others; difficulty concentrating in the learning process and carrying out daily activities that require attention, so often reprimanded and even scolded by parents at home because the room is dirty and messy and lacks attention or is indifferent to problems that exist in the family, is not sensitive to the interaction of fellow family members, so that there is no warmth, affection and care for each other in family members.

\section{Suggestion}

1. Parents are expected not to turn a blind eye to current technological advances, so they can monitor and limit children's habits in using the internet, besides those parents are also expected to provide sex education to children from an early age.

2. The Indonesian Borneo Madani Foundation and the Health and Social Institutions are expected to develop therapeutic programs so that they can be used as an intervention model for treating depression, as well as providing shorter and easier services. 
3. The government is expected to be more serious in overcoming the problem of pornography in teenagers, such as blocking all existing pornographic sites without being able to be accessed using any application or password

\section{References}

1. Permana AS. Kampanye Anti Pornografi. Dr Diss. 2013;4(1):47-56.

2. Rachmaniar R, Prihandini P, Janitra PA. Perilaku Penggunaan Smartphone dan Akses Pornografi di Kalangan Remaja Perempuan. J Komun Glob. 2018;7(1):1-11.

3. Asrina A, Sudirman R. Efektivitas Penggunaan Media Video Learning Multimedia (Vlm) Terhadap Pengetahuan Infeksi Menular Seksual (Ims) (Studi Pada Waria Di Kota Makassar). J Kesehat. 2020;13(2):91.

4. Kementerian Komunikasi dan Informatika \& UNICEF. Riset Kominfo dan UNICEF Mengenai Perilaku Anak dan Remaja Dalam Menggunakan Internet. Kemkominfo. 2017.

5. Pradoko AMS. Paradigma Metodelogi Penelitian Kualitatif. Yogyakarta: UNY Press; 2017.

6. Supratiknya A. Metodelogi Penelitian Kualitatif \& Kuantitatif Dalam Psikologi. 2015;

7. Moleong LJ. Metodologi penelitian kualitatif. Bandung: PT. Remaja Rosdakarya, 2008; 2008.

8. Sugiyono. Metode penelitian pendidikan : (pendekatan kuantitatif, kualitatif dan R \& D). Bandung: Alfabeta; 2008.

9. Kemenkes. Survei Kemenkes: 97 Persen Anak SMP dan SMA Sudah Mengakses Konten Pornografi - Tribun Jakarta. Kementrian Kesehatan. 2019.

10. Nguyen L V., Tran TH, Nguyen TTA, Nguyen DB, Beazley H, Giang MTT. Exposure to sexually explicit Internet material among adolescents: A study in Vietnam. Heal Psychol Rep. 2021;9(3):1-13.

11. Sebayang WB, Saragih G. Pengaruh edukasi seksual terhadap perilaku seks pranikah pada generasi milenial. JHeS (Journal Heal Stud. 2020;4(1):24-9.

12. Skinner. Treating pornography addiction:the essential tools for recovery. Utah: Growth Climate.; 2005.

13. Hariyani M, Mudjiran M, Syukur Y. Dampak Pornografi Terhadap Perilaku Siswa dan Upaya Guru Pembimbing untuk Mengatasinya. J Ilm Konseling. 2012;1(2):1-8. 